\title{
MITÄ ON KOULUTUKSEN LAATU?
}

A ikuiskoulutuksen kielipelissä uusimpia muoti-ilmiöitä on laatu. Sitä käytetään kuvaamaan kaikkea hyvää ja kaunista ilman, että sen merkitystä yleensä millään lailla määritellään. Koulutusorganisaatiot kuvaavat toimintaansa laadukkaaksi. Koulutustoiminnan ja koulutuksen tulosten arviointi näyttäytyy laadun arviointina. Kilvan kehitetään erilasia standardeja ja mittareita, joiden avulla vangitaan laatu paperille tukemaan koulutusorganisaation imagoa ja markkinakelpoisuutta.

Laatu on tullut koulutuskeskusteluun yrityselämästä, jossa laatuajattelu on elänyt jo 50luvulta asti. Laatua on käytetty kuvaamaan japanilaista tuotantoon ja johtamiseen liittyvää ajattelutapaa. Se on muodostunut japanilaisen talouselämän kilpailukyvyn symboliksi, jota länsimaisetkin organisaatiot hanakasti tavoittelevat.

Perinteisesti laatu on ollut tekninen, insinööritieteisiin kuuluva periaate. Laadun kehittäminen tähtää virheettömien, tasalaatuisten tuotteiden tuottamiseen. Merkittävää on asiakkaiden tyytyväisyys tuotteisiin. Pikkuhiljaa laatuajattelu on kuitenkin muotoutunut tuotannon loppupään tarkistuksesta koskemaan koko tuotantoprosessia, tuotesuunnittelua, markkinointia, myyntiä ja asiakaspalvelua. Laatuajattelusta on muodostunut johtamisen väline.

Laatukäsitteen käyttö on yleistynyt myös koulutussektorin kaikilla tasoilla viimeisten viiden vuoden aikana. Suomessakin on parin vuoden kuluessa käynnistetty kymmeniä erilaisia laadun arviointiprojekteja, joista on tähän lehteen valittu joitakin esimerkkejä. On mielenkiintoista pohtia, mikä on aiheuttanut tällaisen yht' äkkisen tarpeen arvioida koulutuksen ja koulutusorganisaatioiden laatua? Yhtenä syynä on ai- nakin kansainvälisten virtausten seuraaminen pienellä viiveellä.

$\mathbf{M}$ itä sitten laatu tarkoittaa aikuiskoulutuksessa? Onko se kurssien tasalaatuisuutta, kurssihallinnon toimivuutta vai koulutustoiminnan hyödyllisyyttä asiakkaille? Onko se taloudellista toimintaa vai laatustandardien sisälleajoa?

Tulisiko laatua tarkastella koko koulutusorganisaation näkökulmasta, kurssin tai koulutusohjelman tasolla vaiko yksittäisen opetustapahtuman tasolla? Minkä sidosryhmän näkökulma on tärkein, mikä rooli on kouluttajien, koulutettavien tai koulutettavien työnantajan käsityksillä? Onko laadussa keskeistä jonkun tyytyväisyys, koulutettavan oppiminen, koulutuksen edullinen toteuttaminen vai ulkoiset puitteet?

Voidaan myös pohtia sitä, miten tuotannosta ja johtamisesta lainattu ajattelutapa toimii koulutusympäristössä. Jos oppijasta itsestään lähtevää kehittymis- ja kehitysprosessia pidetään tuotteena, se on hyvin erilainen kuin teollisuuden tai vaikkapa kaupan ja hallinnon alan tuote. Koulutuksen laadusta puhuttaessa kuitenkin harvemmin otetaan huomioon koulutusorganisaation keskeisin tehtävä sekä koulutustoiminnan sisältö ja muoto.

$\mathbf{K}$ oulutuksen arvioinnissa laatua kuvataan sekä määrällisin että kuvailevien indikaattorien avulla. Melko yleinen on myytti siitä, että jos koulutukselle voidaan asettaa tavoitteita, niiden saavuttamista voidaan myös arvioida. Monien tavoitteiden osalta mitattavuuden vaatimus on kuitenkin osoittautunut mahdottomaksi, kuten laadun kehittämisen uranuurtaja Deming on uudessa teoksessaan osoittanut. 
Laatu on aina suhteellista. Se riippuu valittavista kriteereistä ja mittaustavoista. Laatu on silloin sitä, millaisena se milloinkin nähdään tai mitä eri laatumittarit mittaavat. Sama koulutus voi tällöin olla sekä laadukasta että huonolaatuista.

$\mathbf{L}$ aadun arvioinnin lisäksi puhutaan laadun kehittämisestä. Laatu muodostuu prosessissa, jossa koko ajan tietoisesti vaikutetaan oppimiseen, koulutuksen ja kehittymisen etenemiseen. Laatu määritellään yhteisissä keskusteluissa ja toiminnassa ja sen määrittely muuttuu prosessin edetessä. Laadusta tulee tällöin toimintaa ohjaava periaate.

Laadun kehittäminen koulutusorganisaatiossa ei voi rakentua yksinomaan johtamiselle ja organisoimiselle. Keskeisintä laadun kehittämisen kannalta on se oppimisprosessi, jota oppija toteuttaa koulutuksessa yhteistyössä muiden oppijoiden sekä kouluttajien ja muiden asiantuntijoiden kanssa. Koulutuksen laatua tarkasteltaessa tätä näkökulmaa ei pitäisi unohtaa.

$\mathbf{K}_{\text {s }}$ oulutuksen laatukäsitteen monipuolisuus, suhteellisuus ja epämääräisyys näyttäytyy myös tämän aikuiskasvatuslehden laatunumeron sisällöissä. Tämän teemanumeron tavoitteena on tuoda esille, mitä laadun arvioinnilla on ymmärretty Suomessa, mihin se on kohdistunut ja miten arvioinnit on toteutettu.

Artikkelit rakentuvat osin samoista perusteista, niissä löytyy joitakin samoja lainauksia ja näkökulmia. Toisaalta löytyy arvioinnin kohteiden koko monipuolinen kirjo lyhytkurssitoiminnan laatustandardeista koulutusohjelmien ja koko koulutusorganisaation kehittämiseen. Arvioinnin kohteet vaihtelevat projektista toiseen. Mi- tään yleistä ja yhteistä teoreettista pohjaa ei niistä ole löydettävissä.

Useimmissa tämän lehden kirjoituksissa laadun kehittämisen tavoitteena on tukea oppilaitosten sisäistä kehittämistä. Osassa tulee esille valtiovallan halu seurata ja kontrolloida jonkin koulutussektorin toimintaa. Useimmat projektit on toteutettu valtiovallan rahoituksella ja tuella. Eräissä projekteissa on käytetty päätoimisia asiantuntijoita, osa on toteutettu muiden töiden ohella.

Kaikkia kirjoituksia leimaa suuri usko laadun arvioinnin tarpeeseen ja hyödyllisyyteen. Hyödyn arviointi on kuitenkin vielä melko vaikeasti arvioitavissa tämän lehden kirjoitusten perusteella. Esimerkiksi Hollannissa ja Englannissa esille tullutta hyvinkin kriittistä suhtautumista laadun arvioinnin merkitykseen ei meillä Suomessa vielä ole tullut esille.

$\mathbf{K}$ oulutuksen laatua koskevassa tarkastelussa ollaan edetty vaiheeseen, jossa välttämättä tarvitaan pedagogista näkökulmaa. Tuotannon ja johtamisen ajattelu- ja toimintamallit antavat hyvin virikkeitä pohdiskella laadun problematiikkaa, mutta ilman syvällistä koulutuksen perusprosessien analyysiä laadusta tulee mekaaninen ja ulkokohtainen kehikko hallinnoida ja organisoida koulutusta.

On myös hyvä muistaa, että innostunut, ammattitaitoinen ja päämääränsä tunteva henkilökunta on paras koulutusorganisaation laadun tae. Sitä ei voi arvioinneilla ja tarkastuksilla kompensoida, vaikka ne ovatkin oivia työkaluja kehittämistyössä.

\section{Kauko Hämäläinen ja Antti Kauppi}

